DOI: https://doi.org/10.47405/mjssh.v5i1.348

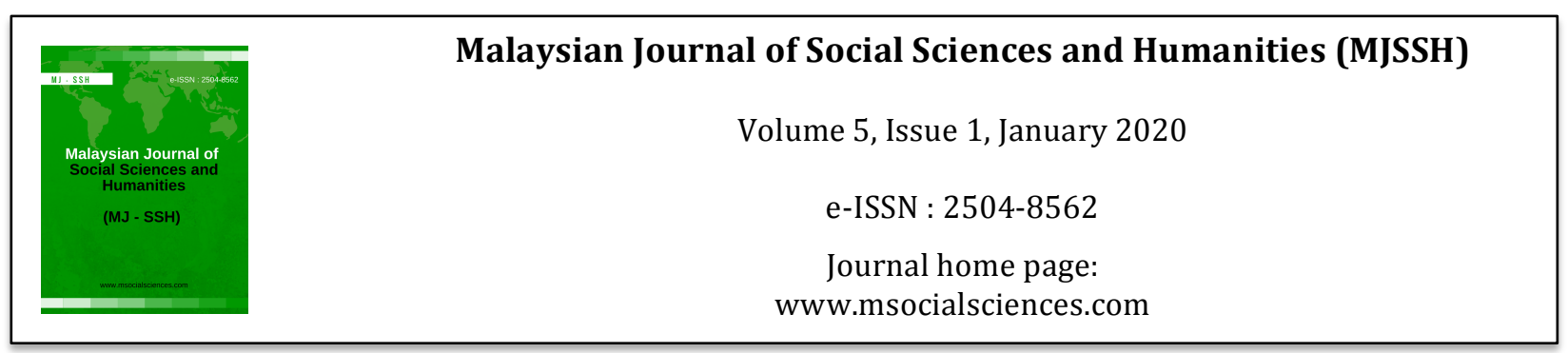

\title{
Pelancongan Bandar Diraja: Satu Pola Kunjungan Pelancong Domestik di Kuala Kangsar
}

\author{
Zurina Ahmad Saidi' ${ }^{1}$, Habibah Ahmad', Hamzah Jusoh'1 \\ ${ }^{1}$ Pusat Pembangunan, Sosial dan Kelestarian, Fakulti Sains Sosial dan Kemanusiaan, Universiti Kebangsaan Malaysia \\ (UKM)
}

Correspondence: Habibah Ahmad (ha@ukm.edu.my)

\begin{abstract}
Abstrak
Pelancongan Bandar Diraja merupakan salah satu produk pelancongan yang semakin mendapat tempat dalam kalangan pelancong domestik di Malaysia. Produk pelancongan merupakan aset penting dalam melengkapkan sesebuah destinasi pelancongan. Kini, Malaysia turut menerima kesan positif menerusi pembangunan pelancongan Bandar Diraja kerana keunikan dan tarikan utamanya telah menjadikan ia salah satu destinasi pelancongan bagi pelancong domestik dan antarabangsa. Makalah ini bertujuan untuk mengenal pasti cirian kunjungan berdasarkan segmen pelancong domestik ke Bandar Diraja Kuala Kangsar. Teknik pensampelan secara kebetulan digunakan bagi sampel kajian sebanyak 500 pelancong. Data kajian diperoleh melalui edaran borang soal selidik di Bandar Diraja Kuala Kangsar, Perak yang melibatkan tiga zon berbeza iaitu di sekitar kawasan bangunan bersejarah seperti muzium, galeri dan arkib serta di masjid, kawasan lembah Sungai Perak dan tapak-tapak pesta di kawasan Majlis Perbandaran Kuala Kangsar. Hasil analisis menunjukkan tidak terdapat perbezaan ketara dalam cirian kunjungan daripada segmen pelancong domestik. Pelancong domestik menunjukkan bahawa terdapat kunjungan bagi kelima-lima tapak pewartaan yang ada. Dari aspek keperluan perkhidmatan juga menunjukkan pola sama bagi kesemua pelancong yang mengunjungi Bandar Diraja Kuala Kangsar.
\end{abstract}

Kata kunci: pola kunjungan, pelancongan Bandar Diraja, pelancong domestik, Bandar Diraja Kuala Kangsar

\section{Royal City Tourism: A Pattern of Visiting According to Domestic Tourist at Kuala Kangsar}

\begin{abstract}
Royal City Tourism is one of the most popular tourist products in Malaysia. Tourism products are an important asset in complementing a tourism destination. Today, Malaysia is also gaining positive impact on the development of the Royal City's tourism as its uniqueness and attractiveness make it one of the top tourist destinations for domestic and international tourists. This paper aims to identify the characteristics of visits based on the domestic tourist segment to Kuala Kangsar. The sampling technique was incidentally used for a sample of 500 tourists. The research data was obtained through the distribution of questionnaires in the City of Kuala Kangsar, Perak which involved three different zones, such as surrounding historic buildings such as museums, galleries and archives, as well as in mosques, Sungai Perak valleys and festivals in the Kuala Municipal Council area Sick. The analysis showed that there was no significant difference in the characteristics of visits from the domestic tourist
\end{abstract}


segment. Domestic tourists indicate that there are visits to all five news sites available. In terms of service requirements it also shows the same pattern for all tourists visiting Kuala Kangsar Royal City.

Keywords: characteristic of visit, Royal Town Tourism, domestic tourists, The Royal City of Kuala Kangsar

\section{Pengenalan}

Bandar Diraja merupakan produk pelancongan yang penting di dalam pertumbuhan dan pembangunan produk pelancongan di Malaysia. Menurut Blank (1994) ia merupakan salah satu destinasi wajib kepada penggemar sejarah dan pengalaman pelancongan berbentuk warisan sejarah, alam semula jadi, pembuatan manusia sejarah yang bersifat ketara dan tidak ketara. Terdapatnya perkaitan antara pelancongan warisan dengan Bandar Diraja dalam menarik minat pelancong domestik dan antarabangsa. Peningkatan tarikan warisan ini akhirnya dilihat sebagai cabaran yang berpotensi untuk menjelaskan keunikan-keunikan yang terdapat di Bandar Diraja sebagai produk pelancongan.

Pelancongan Bandar Diraja kian popular dalam kalangan masyarakat tempatan hari ini. Namun begitu, walaupun semakin dikenali dengan kepesatan penyampaian maklumat, ia juga masih baru dalam konteks pembangunan dan penyelidikan di Malaysia. Bagi mempromosikan Bandar Diraja sebagai produk pelancongan, Bandar Diraja itu sendiri mesti berdiri sebagai satu institusi yang menarik dan unik. Koleksi, pameran, bangunan, kemudahan pelancong dan program-program awam antara medium yang perlu diketengahkan dengan berkesan. Potensi Bandar Diraja sebagai produk pelancongan adalah tinggi kerana faktor budaya, kesenian, warisan serta aktiviti kesenian dicatatkan sebagai di antara lima sebab utama yang menarik aktiviti pelancongan (NEA 1999). Hal ini disokong sewaktu WHSTT 'people don't come to America for our airports, people don't come to America for our hotels...They come here for our culture: high culture, middle culture, right, left, real, imagine, .they come here to see America'.

Umumnya, pelancongan merupakan satu pendekatan kolektif yang mengetengahkan pelancong sebagai pelanggan (Anuar et al. 2012). Seterusnya, Khospakyants \& Vidisheva (2010) menjelaskan 70\% pelancong mempunyai tujuan-tujuan tertentu dan mereka adalah individu utama dalam memajukan industri pelancongan. Hal ini disokong oleh Anuar et al. (2012) yang menjelaskan bahawa pelancong adalah pelanggan utama. Pencirian dalam penyertaan-penyertaan acara pelancongan yang viral mempunyai hubungan signifikan untuk mencapai matlamat sesebuah acara pelancongan dengan penyertaan pelancong dari luar dan dalam negara (Mair \& Withford 2013). Pelancongan menekankan kepada kriteria pelancong yang sifatnya berubah-ubah mengikut topik, trend dan pertumbuhan berkala dalam pelancongan dan ia berkepentingan kepada pencirian pelancong antarabangsa khususnya (Kim et al 2013). Pada sisi yang lain, kajian-kajian terdahulu banyak memfokuskan kedatangan pelancong antarabangsa ke Malaysia menerusi pelancongan acara, festival dan kebudayaan, namun demikian, terdapat jurang antara pelancong domestik dan pelancong antarabangsa di Malaysia. Laporan Jabatan Perangkaan Malaysia (2017) berdasarkan prestasi pelancongan domestik 2016 mendapati peningkatan sebanyak 7\% sebanyak 189.3 juta pelancong domestik direkodkan berbanding pada tahun 2015 serta bilangan perjalanan meningkat $8 \%$ iaitu 253. 9 juta. Terdapat lima negeri tumpuan pelancong domestik iaitu Selangor dengan kehadiran pelancong sebanyak 24.0 juta, Perak (16.8 juta), Wilayah Persekutuan Kuala Lumpur (16.8 juta), Sabah (16.5 juta) dan Sarawak (16.3 juta).

Pelancongan Bandar Diraja Kuala Kangsar kini menjadi tumpuan dan tarikan menerusi kempen 'CutiCuti 1Malaysia Dekat Je' yang dilaksanakan pada bulan Jun 2015 (Jabatan Warisan Negara 2018). Peningkatan kehadiran pelancong domestik merupakan matlamat utama negara untuk mengurangkan aliran keluar mata wang di samping menggalakkan masyarakat Malaysia bercuti di lokasi tempatan dan ini menunjukkan bahawa peranan dan sumbangan pelancong domestik. Menurut Anuar et al. (2014) menjelaskan bahawa pelancong domestik mempunyai perkaitan yang tinggi dalam setiap aktiviti, produk dan penawaran oleh penyedia perkhidmatan. Ini membuktikan pelancong domestik tidak boleh 
dipinggirkan dalam memastikan kemenjadian pembangunan pelancongan di Malaysia. Oleh itu, kajian berkaitan dengan perspektif pelancong domestik perlu secara menyeluruh dan holistik.

Untuk menjamin kehadiran pelancong domestik ke Bandar Diraja, pelbagai isu berkaitan dengan Bandar Diraja harus diberi perhatian. Ini tidak terkecuali bagi isu cirian pelancong domestik terhadap destinasi pelancongan Bandar Diraja. Bentuk penglibatan pelancong domestik ke Bandar Diraja dilihat masih tidak jelas berbanding dengan penglibatan pelancong di negara luar (Habibah et al. 2007; Mackellar 2013; Ghaffar et al. 1992). Mekanisme cirian pelancong yang melancong ke Bandar Diraja dilihat masih kabur dan tiada data rujukan kehadiran pelancong ke Bandar Diraja. Walau bagaimanapun, tidak terdapat bukti empirik yang wujud menjelaskan mekanisme cirian tersebut. Pencirian pelancong domestik Bandar Diraja merupakan panduan dalam perkembangan pelancongan warisan. Lanjutan daripada isu pencirian Bandar Diraja ini, Wall (1994) menyatakan bahawa perubahan pelancongan Diraja membentuk pencirian yang khusus, tepat dan boleh diterima. Oleh hal yang demikian, adakah wujud atau tidak perbezaan antara segmen pelancong domestik?

Berasaskan kepentingan dalam membangunkan pelancongan Bandar Diraja, langkah mengenal pasti sejauh mana perspektif pelancong domestik terhadap Bandar Diraja dilihat adalah relevan. Lebih tepat lagi, adalah wajar satu kajian dilakukan untuk membangunkan pelancongan Bandar Diraja dari perspektif pelancong domestik. Oleh itu, artikel ini bertujuan untuk mengenal pasti cirian kunjungan pelancong domestik di Bandar Diraja Kuala Kangsar. Makalah dapat menyumbang kepada usaha mempromosikan dan memperkasakan salah satu produk pelancongan menerusi pandangan pelancong domestik.

\section{Bandar Diraja}

Bandar dilihat sebagai sumber penting dalam sosial dan kumpulan individu dalam memberikan kesan kepada pertumbuhan ekonomi, amalan demokrasi, kualiti tadbir urus dan kualiti kehidupan. Menurut Blank (1994), lokasi bandar yang mempunyai populasi yang tinggi, menawarkan pengalaman kebudayaan, kesenian dan rekreasi akan menarik minat pelancong untuk berkunjung. Menurut Tedd (2010), kemaslahatan bandar membuatkan kita menjadi lebih bijak, sihat, selamat, kaya dan boleh mentadbir dengan baik dan mempunyai kestabilan demokrasi. Hal ini menjelaskan bahawa untuk memahami konsep bandar sosial adalah mempunyai rangkaian sosial dan nilai-nilai kepercayaan serta timbal balas melalui rangkaian sosial.

Bandar Diraja merupakan sebuah bandar yang menekankan elemen-elemen warisan sejarah dan lebih memfokuskan kepada warisan ketara seperti istana, bangunan pembesar, kedai lama, muzium dan galeri serta lain-lain monumen- monumen yang terdapat di sesebuah bandar tersebut. Bandar Diraja merupakan salah satu yang dijadikan skop usaha pemeliharaan dan pemuliharaan warisan (Tedd 2010).

Sesebuah Bandar Diraja bergantung kepada sumber modal jangka panjang terhadap proses perkembangan sejarah (Borg et al. 1996). Kekuatan modal merupakan pantulan kepada kualiti hubungan sosial serta rangkaian kepada bandar warisan tersebut. Terdapatnya perasaan yang menghubungkan, kepercayaan serta kewujudan cara-cara tradisional serta beberapa kemahiran dan pengeluaran hasil daripada kreativiti kraf tradisional dan aktiviti-aktiviti pertanian untuk pembangunan di Bandar Diraja. Sebagai perlambangan Bandar Diraja, menurut Fenton (2007) menjelaskan seni dapat memupuk dan mengukuhkan persahabatan dan hubungan, membantu komuniti dalam memahami dan meraikan warisan di Bandar mereka. Di samping itu menyediakan dan menyelesaikan masalah sosial serta mengatasi perubahan budaya yang perlahan-lahan berubah. Hal ini kerana sempadan demografi dilihat boleh memecahbelahkan masyarakat dalam menghubungkan masyarakat di satu-satu bandar utama.

\section{Warisan Bandar Diraja}

Bandar Diraja sentiasa menjadi teras kepada warisan dan seni dunia. Sebagai contoh La Scala, Muzium British dan Pompeii yang telah berabad lama dikenali sebagai suatu warisan sejarah yang mempunyai 
estetika dan budaya institusi tersebut. Namun demikian, warisan estetika ini menjadi isu yang amat sukar dalam menyeimbangkan kerana berlakunya kuasa-kuasa baru dan tekanan terhadap orientasi pasaran dan perhatian, kewangan dan manusia (Tao 2011).

Warisan telah diperturunkan dari generasi ke generasi. Ia merupakan tinggalan nenek moyang ataupun tinggalan alam semula jadi yang dipelihara dengan baik mahupun sedang dipulihara oleh sesebuah agensi. Menurut Adi (2001) menyatakan bahawa warisan bermaksud suatu tinggalan yang menjadi kebanggaan dan pengenalan kepada sesuatu bangsa kepunyaannya. Warisan kini menjadi suatu sumber jangka panjang kerana kelebihan daya saing dengan negara lain atas faktor perubahan dan cabaran yang dihadapi seperti perkembangan teknologi, penjenamaan dan lain-lain (Garcia 2007). Oleh hal ini, unsur sejarah dan warisan perlu diserlahkan untuk kestabilan dan perkembangan pada masa hadapan. Ia diakui sebagai sumber penyampaian sejarah dan warisan kepada pelancong terhadap keunikan dari segi tarikan dan persediaan pembangunan yang tinggi (Balmer 2009). Menurut Sims (2002) menjelaskan warisan merupakan kunci kepada perlindungan sejarah pada masa hadapan. Namun demikian, terdapat pelbagai cabaran dalam memastikan kejayaannya kerana persekitaran kini menuntut kepada identiti warisan yang kukuh dan tiada unsur tiruan.

Warisan budaya yang menonjolkan sisi sesebuah negara mempunyai kesan kekal pada nilai seorang individu dan dianggap relevan pada masa kini kerana ia mengekalkan nilai-nilai sejarah (Inglehart \& Baker 2000). Namun begitu, untuk mengekalkan nilai-nilai sejarah kepada seorang individu adalah sukar dan tidak mudah kerana fikiran yang berbeza-beza dan kolektif. Bagi mengekalkan warisan sejarah, pembangunan kendiri individu perlu dipertingkatkan dari semasa ke semasa.

Setiap negara mempunyai warisan yang berbeza-beza mencangkup nilai dan perbandingan (Ula et al. 2011). Hal ini kerana menurut Banerjee (2008) menjelaskan untuk mengukur budaya warisan sesebuah negara ia perlu berlandaskan kepada kehomogenan iaitu bermaksud kepelbagaian, kestabilan, toleransi dan halangan-halangan. Potensi warisan dan aktiviti kebudayaan dikaitkan dengan pendekatan konvensional kepada pemeliharaan, pemuliharaan, tafsiran kontemporari dan penggunaannya.

\section{Pelancongan Bandar Diraja}

Pelancongan Bandar Diraja merupakan satu produk pelancongan yang dapat memberikan kepuasan kepada pelancongan di destinasi bersejarah yang selamanya hanya berada di sana. Pelancongan Bandar Diraja mempunyai sifat dan tradisi, mengubah bentuk budaya dan alam semula jadi dan ia bukanlah hanya menjalankan aktiviti-aktiviti pelancongan semata-mata. Jadi, pelancongan Bandar Diraja lebih menekankan kepada konsep seperti makanan dan perayaan, aktiviti bersama dengan hobi yang hampir sama, perbincangan mengenai isu masyarakat, melaksanakan program untuk mencapai matlamat bersama serta menjalinkan hubungan dan membentuk jaringan industri yang erat (Natalie 2016). Namun demikian, ia bergantung kepada saiz Bandar Diraja serta kemahiran sosial yang tinggi dalam kalangan masyarakat untuk meningkatkan interaksi dan hubungan bersama-sama masyarakat lain (Prentice \& Cunnel 1998).

Selain itu, pelancongan Bandar Diraja menekankan aspek kepelbagaian aktiviti sosial yang dijalankan pada masa dahulu dan berkekalan sehingga kini dan dipertontonkan kepada pelancong masa kini. Hal ini disokong oleh Candida Fenton (2007) yang menjelaskan terdapat aktiviti yang membantu mewujudkan sumber-sumber sosioekonomi di bandar. Perhatian utama adalah untuk merapatkan hubungan sosial dalam kalangan masyarakat (Prentice \& Cunnel 1998). Ini membuktikan bahawa aktiviti sosial seperti pelancongan adalah penting dan berharga. Oleh itu, Fenton (2007) mencadangkan lima arena institusi yang menjadi tumpuan dalam memfokuskan kepada aktiviti yang membolehkan masyarakat membangunkan pelancongan Bandar Diraja adalah tempat kerja, artis dan pertubuhan warisan, politik dan governans, rumah ibadah dan sekolah serta pertubuhan belia dan keluarga.

Pelancongan Bandar Diraja terkenal dengan warisan sejarah yang telah pun ditinggalkan beribu tahun dahulu sewaktu zaman kegemilangan dan kesan beberapa negara yang datang menjajah. Oleh itu, pelbagai budaya yang unik dikesan untuk dijadikan sebagai tarikan pelancong untuk datang ke Bandar Diraja menjelaskan bahawa pelancong yang melancong ke bandar warisan seperti ini suka melihat 
pemandangan yang indah, tempat bersejarah, meneroka saintifik, kesenian rakyat dan pembuatan kraf serta mempelajari adat dan kebudayaan.

\section{Metod Kajian}

Kajian ini menggunakan kaedah kuantitatif bagi mengenal pasti cirian pelancong domestik. Kajian berbentuk pendekatan kuantitatif menggunakan Teknik Persampelan Secara Kebetulan (convenience sampling) yang melibatkan 500 pelancong. Set soalan mengandungi 3 bahagian. Bahagian pertama untuk memperoleh maklumat demografi pelancong, bahagian kedua merupakan cirian kunjungan pelancong ke Bandar Diraja di Malaysia dan bahagian ketiga adalah cadangan. Bagi cirian kunjungan melibatkan aktiviti utama, faktor utama, faktor sokongan dan sumber maklumat. Data dianalisis dan diproses melibatkan analisis deskriptif (frekuensi dan peratusan) dan analisis inferensi (ANOVA Dua Hala). Pemprosesan data dilaksanakan dengan menggunakan sistem perisian Statistical Packages for Social Sciences (SPSS) version 22.0. Hasil kajian rintis menggunakan analisis Cronbach Alpha bagi semua konstruk adalah berada di tahap kebolehpercayaan yang tinggi iaitu di antara 0.855 hingga 0.957 .

\section{Kawasan Kajian}

Pemilihan kes kawasan kajian telah dilaksanakan di tiga zon berbeza di Bandar Diraja Kuala Kangsar iaitu zon pertama adalah sekitar kawasan bangunan seperti di Masjid Ubudiah Bukit Chandan, Istana Kenangan Bukit Chandan, makam-makam Diraja dan Pusat membeli-belah. Zon kedua adalah kawasan lembah yang menjadi tumpuan dan bersebelahan dengan sungai Perak. Manakala zon ketiga adalah di tapak-tapak pesta anjuran Majlis Perbandaran Kuala Kangsar (MPKK) seperti Pesta Orkid, Pesta Kembali Ke Sekolah dan Pesta Air. Ketiga-tiga zon ini dipilih kerana ia merupakan kawasan tumpuan pelancong yang berkunjung serta terdapat pelbagai pilihan produk-produk kesenian dan warisan Diraja dan merupakan pilihan hotspot pelancong. Pergerakan corak edaran adalah bermula dengan zon pertama, diikuti dengan zon kedua dan seterusnya zon ketiga.

\section{Hasil Kajian}

\section{Profil Pelancong}

Pelancong dalam kajian ini terdiri daripada $65.8 \%$ (329 orang) perempuan dan $34.2 \%$ (171 orang) lelaki. Lebih 30\% pelancong berumur dalam lingkungan20-25 tahun diikuti 15-19 tahun sebanyak $22.0 \%$ (110 orang). Ini menjelaskan kebanyakan pelancong merupakan golongan belia aktif yang menjadikan melancong sebagai aktiviti wajib. Seterusnya didapati kunjungan ke Bandar Diraja Kuala Kangsar adalah majoriti pelancong Melayu sebanyak 88.6\% (443 orang) manakala Cina dan India adalah sebanyak $7.0 \%$ (35 orang) dan 4.4\% (22 orang). Seterusnya, 47.0\% (235 orang) pelancong menunjukkan mereka mempunyai pendidikan Ijazah Sarjana Muda dari dalam dan luar negara. Pelancong terdiri daripada mereka yang mempunyai pendidikan Sijil Tinggi Pelajaran sebanyak 32.4\% (162 orang) dan pendidikan Doktor Falsafah sebanyak 1.0\% (5 orang). Lebih 60\% pelancong berstatus bujang, diikuti pelancong yang berkahwin dan berkeluarga sebanyak 28.6\% (143 orang) serta yang berstatus duda/ janda sebanyak $2.6 \%$ (13 orang).

Jadual 1: Profil Pelancong

\begin{tabular}{llccc}
\hline \multicolumn{1}{c}{ Komponen } & & Kategori & Bilangan & Peratus \\
\hline Jantina & Lelaki & 171 & 34.2 \\
& Perempuan & 329 & 65.8 \\
Kategori & Pelajar & 104 & 20.8 \\
& Belia & 239 & 47.8 \\
& Keluarga & 157 & 31.4 \\
Umur & $15-19$ & 110 & 22.0 \\
\hline
\end{tabular}


DOI: https://doi.org/10.47405/mjssh.v5i1.348

\begin{tabular}{|c|c|c|c|}
\hline & $20-24$ & 169 & 33.8 \\
\hline & $25-29$ & 95 & 19.0 \\
\hline & $30-34$ & 71 & 14.2 \\
\hline & $35-39$ & 23 & 4.6 \\
\hline & $40-44$ & 15 & 3.0 \\
\hline & $45-49$ & 12 & 2.4 \\
\hline & $50>$ & 5 & 1.0 \\
\hline \multirow[t]{3}{*}{ Etnik } & Melayu & 443 & 88.6 \\
\hline & Cina & 35 & 7.0 \\
\hline & India & 22 & 4.4 \\
\hline \multirow[t]{5}{*}{ Pendidikan } & Sijil Pelajaran Malaysia (SPM) & 162 & 32.4 \\
\hline & Diploma / STPM & 26 & 5.2 \\
\hline & Ijazah Sarjana Muda & 235 & 47.0 \\
\hline & Ijazah Sarjana & 72 & 14.4 \\
\hline & Doktor Falsafah & 5 & 1.0 \\
\hline \multirow[t]{3}{*}{ Status perkahwinan } & Bujang & 344 & 68.8 \\
\hline & Berkahwin & 143 & 28.6 \\
\hline & Janda/ Duda & 13 & 2.6 \\
\hline \multirow[t]{6}{*}{ Pekerjaan } & Pengurusan Tertinggi & 16 & 3.2 \\
\hline & Kumpulan Profesional & 108 & 21.6 \\
\hline & Berniaga/ Bekerja Sendiri & 28 & 5.6 \\
\hline & Kumpulan Teknikal/ Pertengahan & 20 & 4.0 \\
\hline & Kumpulan Sokongan & 72 & 14.4 \\
\hline & Tidak Bekerja & 256 & 51.2 \\
\hline \multirow[t]{5}{*}{ Sektor Pekerjaan } & Kerajaan & 134 & 26.8 \\
\hline & Swasta & 71 & 14.2 \\
\hline & Persendirian & 25 & 5.0 \\
\hline & Tidak Bekerja & 14 & 2.8 \\
\hline & Pelajar & 256 & 51.2 \\
\hline Pendapatan & Tiada Pendapatan & 245 & 49.0 \\
\hline \multirow{6}{*}{ Bulanan Isi Rumah } & < RM2000 (B40) & 57 & 11.4 \\
\hline & RM 2001 - RM 3000 (B40) & 46 & 9.2 \\
\hline & RM3001 - RM 3860 (B40) & 54 & 10.8 \\
\hline & RM 3861 - RM 6090 (M40) & 71 & 14.2 \\
\hline & RM 6091 - RM 8320 (M40) & 21 & 4.2 \\
\hline & $>$ RM8321 & 6 & 1.2 \\
\hline
\end{tabular}

$\mathrm{N}=500,100$ peratus

Dari segi ekonomi, pelancong yang tidak bekerja sebanyak 51.2\% (256 orang) kerana mereka merupakan golongan pelajar dan belia yang masih belajar di Institusi Pengajian Tinggi (IPT) dan Sijil Pelajaran Malaysia (SPM). Pelancong yang bekerja merupakan kumpulan profesional seperti guru, doktor, jurutera, akauntan, eksekutif, pegawai tadbir, pengurus dan pensyarah adalah sebanyak $21.6 \%$ (108 orang) serta lain-lain pekerjaan seperti berniaga kumpulan teknikal serta kumpulan sokongan. Seterusnya pelancong dari sektor kerajaan adalah paling ramai iaitu 26.8\% (134 orang) dan pelancong yang bekerja di sektor swasta sebanyak 14.2\% (71 orang).

Dari segi pendapatan isi rumah, hampir $50 \%$ pelancong tidak mempunyai pendapatan tetap. Walau bagaimanapun sebanyak $14.2 \%$ (71 orang) mempunyai pendapatan sebanyak RM3861 - RM6090 (M40). Ini diikuti pelancong yang mempunyai pendapatan sebanyak $<$ RM2000 iaitu $11.4 \%$ (57 orang). Seterusnya sebanyak $20 \%$ daripada 500 pelancong memperoleh pendapatan sebanyak RM2001RM3860 (B40). Bagi pendapatan sebanyak RM6091 - RM8320 (M40) dan >RM8321 masing-masing mencatatkan sebanyak $4.2 \%$ (21 orang) dan $1.2 \%$ (6 orang). Terdapat tiga kategori pelancong domestik iaitu pelajar sebanyak 20.8\% (104 orang), belia sebanyak $47.8 \%$ (239 orang) dan keluarga sebanyak $31.4 \%$ (157 orang).

\section{Tarikan Utama Bandar Diraja Kuala Kangsar}

Lawatan pelancong domestik tidak lengkap tanpa mereka mengunjungi destinasi wajib kunjung sebagai titik tumpuan kunjung an. Jabatan Warisan Negara (JWN) mewartakan lima tarikan utama Kuala Kangsar sebagai produk pelancongan dan ikon kepada destinasi pelancongan. Ikon destinasi 
tersebut adalah Masjid Ubudiah Bukit Chandan, Istana Kenangan Bukit Chandan, Makan Diraja dan Pahlawan, Jambatan Keretapi Victoria dan Bangunan Big School Maktab Melayu Kuala Kangsar (MCKK).

Secara keseluruhannya, rata-rata pelancong domestik mengunjungi kelima-lima destinasi tersebut. Walau bagaimanapun, kunjungan mereka pada kali ini bukan secara menyeluruh kerana kebanyakan daripada destinasi pewartaan sedang dinaiktarafkan dan diubahsuai dalam jangka masa yang lama. Namun, mereka hanya melihat dari luar kawasan pengubahsuaian. Berdasarkan hasil dapatan, sebanyak $88.0 \%$ (440 orang) melawat Jambatan Kereta api Victoria. Kunjungan ini bertepatan dengan lokasi yang strategik iaitu di Seberang Karai, Kuala Kangsar. Bagi pelancong yang berkunjung kali pertama, mereka tidak melepaskan peluang untuk menelusuri jambatan ini untuk melihat sendiri Sungai Perak.

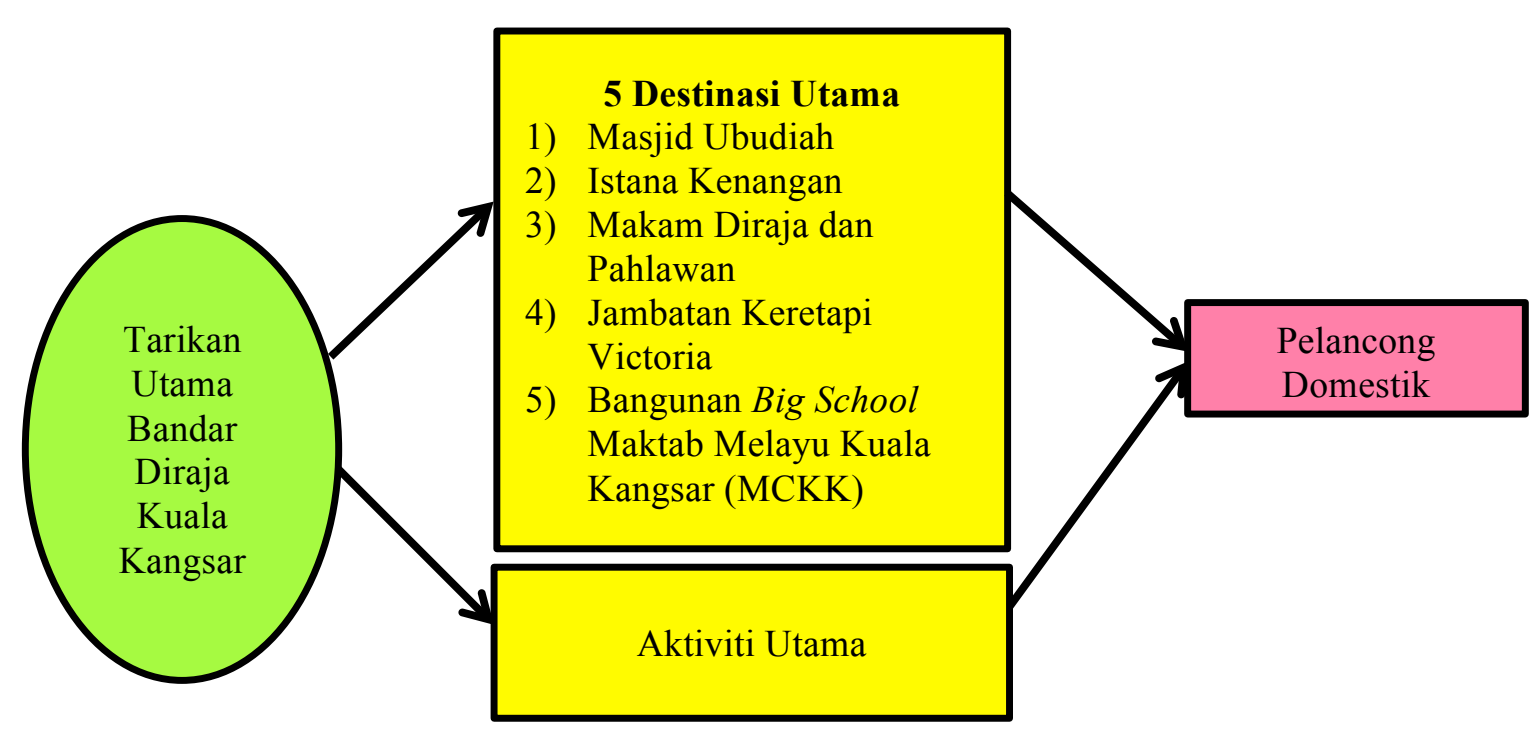

Rajah 2: Tarikan Utama Bandar Diraja Kuala Kangsar

Sebahagian besar pelancong telah mengunjungi Istana Kenangan Bukit Chandan. Istana Kenangan merupakan destinasi wajib kunjung semua pelancong domestik. Persembahan seni bina dan landskap bermula dari tol Kuala Kangsar sehingga ke Istana Kenangan menarik kunjungan mereka. Rata-rata daripada mereka mengabadikan kenangan seperti bergambar, membuat video dan melihat secara lebih dekat. Bergambar di signage Istana Kenangan juga menjadi satu port utama untuk bergambar. Namun demikian, kunjungan mereka tidak secara menyeluruh kerana ia sedang di konservasi semula.

Kunjungan seterusnya adalah di Masjid Ubudiah Kuala Kangsar yang mencatatkan sebanyak 77.4\% (387 orang). Jarak antara Istana Kenangan dan Masjid Ubudiah berdekatan, rata-ratanya tidak melepaskan peluang untuk melawat. Walaupun ketika itu Masjid Ubudiah sedang di dalam pengubahsuaian. Bagi pelancong beragama Islam, mereka tidak melepaskan peluang untuk melaksanakan ibadah solat di ruang yang disediakan. Ini ditegaskan oleh pelancong bahawa bersolat di Masjid ini adalah satu keperluan yang menuntut. Manakala pelancong bukan beragama Islam juga turut serta melawat untuk melihat seni bina unik dan hanya satu-satunya reka bentuk asli di Masjid ini. Terdapat beberapa aktiviti yang sedang berlangsung ketika itu seperti Kelas Mengaji Al-Quran dan Kursus Umrah/Haji pada waktu pagi manakala ceramah agama di sebelah petang selepas Solat Asar.

Umumnya, Masjid Ubudiah mengadakan aktiviti dan program yang terbahagi kepada dua kategori iaitu kuliah ilmu dan aktiviti kemasyarakatan. Kuliah ilmu dijalankan pada hari-hari tertentu, khususnya selepas Maghrib. Aktiviti kemasyarakatan pula dilaksanakan pada tarikh-tarikh yang telah ditetapkan oleh Ahli Jawatankuasa Masjid. Antaranya termasuklah gotong-royong, sambutan perayaan dan program khusus. 
DOI: https://doi.org/10.47405/mjssh.v5i1.348

Kedudukan strategik Bangunan Big School Maktab Melayu Kuala Kangsar (MCKK) di tengah-tengah pusat bandar mendorong pelancong untuk melawat. MCKK dikenali sebagai sebuah sekolah untuk golongan elit Melayu yang terdiri daripada kerabat Diraja. Walau bagaimanapun, kunjungan ini sebanyak $51.8 \%$ (259 orang) sahaja. Hasil mendapati bahawa kebanyakan daripada tapak-tapak lawatan di bandar Diraja Kuala Kangsar sedang dinaiktarafkan dan dibaiki secara berperingkat. Oleh itu, kebanyakan pelancong yang datang berkunjung ke destinasi tarikan yang lain seperti Lembah, pesta bunga yang sedang dilaksanakan dan kawasan simbolik Bandar Diraja di tengah-tengah Pusat Bandaraya. Secara keseluruhannya, pilihan destinasi masih berpihak kepada destinasi yang membentuk pengalaman pelancong domestik.

Jadual 2: Destinasi utama kunjungan

\begin{tabular}{lcccc}
\hline \multicolumn{1}{c}{ Destinasi kunjungan di Kuala Kangsar } & Ya & \% & Tidak & \% \\
\hline Masjid Ubudiah Kuala Kangsar & 387 & 77.4 & 113 & 22.6 \\
Istana Kenangan Bukit Chandan & 427 & 85.4 & 73 & 14.6 \\
Makam-makam Diraja dan pahlawan & 303 & 60.6 & 197 & 39.4 \\
Jambatan Keretapi Victoria & 440 & 88.0 & 60 & 12.0 \\
MCKK & 259 & 51.8 & 241 & 48.2 \\
\hline
\end{tabular}

\section{Aktiviti Utama Kunjungan ke Kuala Kangsar}

Berdasarkan Jadual 3, aktiviti utama kunjungan adalah melawat landskap Bandar Diraja. Terdapat landskap yang memaparkan warisan tinggalan lama seperti mercu tanda replika Labu Sayong, tanda nama jalan, perabot jalan, landskap yang bercirikan flora dan fauna serta lampu-lampu jalan. Landskap Bandar Diraja bukan sahaja di Istana, Masjid dan lain-lain lokasi kunjung wajib pelancong tapi ia adalah secara keseluruhannya. Landskap Bandar Diraja memperkenalkan keindahan Bandar Kuala Kangsar dalam mencerminkan identiti Kuala Kangsar sebagai Bandar Diraja.

Terlalu banyak bangunan lama yang belum dihapuskan atas dasar pembangunan.Ini kerana ia menggambarkan sejarah dan warisan terdahulu dari segi keunikan seni binanya. Antara adalah Rumah Kutai, rumah kedai dan rumah pembesar yang menjadi pilihan sewaktu berkunjung. Terdapat juga pelancong yang menjadikan lawatan ke bangunan lama sebagai tarikan utama kunjungan. Ini kerana mereka sangat meminati seni bina lama yang unik dan dipenuhi dengan ciri-ciri Barat dan tradisional. Ia mendatangkan inspirasi dan ilham kepada penggemar seni bina. Sehubungan dengan itu tidak menghairankan sebilangan daripada responden yang menghabiskan separuh daripada lawatan kunjungan hanya bermotifkan lawatan ke bangunan lama sahaja.

Satu lagi perkara ketara adalah pelancong domestik gemar melawat tempat-tempat bersejarah walaupun mereka bukanlah seorang penggemar sejarah. Antara bangunan bersejarah yang dikatakan wajib kunjung pelancong adalah Masjid Ubudiah, Istana Kenangan dan Istana Iskandariah. Bagi pelancong yang beragama Islam, mereka tidak melepaskan peluang untuk menunaikan solat di Masjid Ubudiah. Walaupun 60\% daripada Masjid Ubudiah sedang dalam kerja-kerja pengubahsuaian, tetapi masih terdapat ruang yang boleh dikunjungi oleh mereka. Masjid Ubudiah sememangnya menjadi tarikan utama pelancong kerana ia dianggap sebagai salah satu masjid terindah di Malaysia.

Komunikasi dengan masyarakat setempat juga adalah satu kemestian sekiranya berada di mana-mana lokasi percutian. Pelancong domestik juga gemar berkenalan dengan pelancong dan penduduk setempat. Ini kerana mereka memerlukan maklumat dan bantuan sekiranya perlu. Penduduk setempat terutamanya orang tua sering bercerita tentang sejarah dan perkembangan Kuala Kangsar. Perkenalan selalunya terjadi di kedai makan mahupun restoran, di taman rekreasi dan Dataran Lembah. Terdapat juga perkenalan secara langsung dan tidak langsung.

Walaupun sebahagian besar daripada mereka tidak menggemari persembahan tradisional, namun ia tidak mengehadkan aktiviti mereka dalam menyertai persembahan tradisional dan perayaan. Kunjungan pelancong domestik kali ini adalah pada musim cuti persekolahan serta di bulan Disember, oleh itu persembahan yang disajikan adalah persembahan perkahwinan tradisional Negeri Perak. 
DOI: https://doi.org/10.47405/mjssh.v5i1.348

Pelancong dapat melihat persembahan kompang, silat, berqasidah dan lain-lain persembahan. Pelancong juga boleh merasai pengalaman merenjis pengantin dan diajar cara-cara merenjis dengan betul serta diberikan bunga telur sebagai cenderamata.

Jadual 3: Aktiviti utama kunjungan

\begin{tabular}{|c|c|c|c|c|c|c|c|c|c|c|c|c|}
\hline \multirow[t]{2}{*}{ Item } & \multicolumn{2}{|c|}{$\begin{array}{l}\text { Sangat } \\
\text { Rendah }\end{array}$} & \multicolumn{2}{|c|}{ Rendah } & \multicolumn{2}{|c|}{ Sederhana } & \multicolumn{2}{|c|}{ Tinggi } & \multicolumn{2}{|c|}{$\begin{array}{l}\text { Sangat } \\
\text { Tinggi }\end{array}$} & \multirow[t]{2}{*}{ Min } & \\
\hline & Bil & $\%$ & Bil & $\%$ & Bil & $\%$ & Bil & $\%$ & Bil & $\%$ & & \\
\hline $\begin{array}{l}\text { Melawat } \\
\text { tempat } \\
\text { bersejarah }\end{array}$ & 9 & 1.8 & 39 & 7.8 & 178 & 35.6 & 208 & 41.6 & 66 & 13.2 & 3.57 & 3 \\
\hline $\begin{array}{l}\text { Melawat } \\
\text { bangunan lama }\end{array}$ & 17 & 3.4 & 53 & 10.6 & 134 & 26.8 & 217 & 43.4 & 79 & 15.8 & 3.58 & 2 \\
\hline $\begin{array}{l}\text { Berkenalan } \\
\text { dengan } \\
\text { pelancong dan } \\
\text { penduduk }\end{array}$ & 29 & 5.8 & 84 & 16.8 & 150 & 30.0 & 139 & 27.8 & 98 & 19.6 & 3.39 & 4 \\
\hline $\begin{array}{l}\text { Melawat } \\
\text { landskap } \\
\text { Bandar Diraja }\end{array}$ & 15 & 3.0 & 44 & 8.8 & 129 & 25.8 & 190 & 38.0 & 122 & 24.4 & 3.72 & 1 \\
\hline $\begin{array}{l}\text { Menyertai } \\
\text { persembahan } \\
\text { tradisional }\end{array}$ & 65 & 13.0 & 59 & 11.8 & 141 & 28.2 & 148 & 29.6 & 86 & 17.2 & 3.26 & 5 \\
\hline
\end{tabular}

\section{Destinasi Sekunder}

Destinasi sekunder memainkan peranan sampingan dalam memastikan pelancong turut berkunjung ke destinasi tersebut. Majoriti daripada pengunjung melawat ke muzium, galeri Sultan Azlan Shah yang terletak di Bukit Chandan. Walaupun pada ketika itu, muzium tersebut sedang diubah suai, mereka tidak melepaskan peluang untuk bersiar-siar di luar bangunan. Ini kerana mereka masih dapat melihat ruang legar galeri yang menarik dari segi seni binanya kerana ia setaraf dengan galeri yang terdapat di luar negara. Persekitaran muzium, galeri dihiasi dengan kolam renang pantulan cahaya. Ia juga masih mengekalkan ciri-ciri Melayu Klasik lama menerusi bahagian bumbung yang berbentuk limas serta pengaruh seni bina India di bahagian kubah yang dapat dilihat dari luar.

Seterusnya, kunjungan pelancong domestik adalah ke Perpustakaan Desa atau dikenali sebagai Perpustakaan Bahan Kesusasteraan yang menempatkan bahan-bahan bacaan Melayu klasik, Melayu lama dan sejarah adat dan warisan penduduk, masyarakat dan komuniti Bandar Diraja Kuala Kangsar. Sebanyak $40.2 \%$ (201 orang) telah berkunjung ke sini. Ini kerana promosi yang dianjurkan pada ketika itu menarik minat pengunjung untuk turut hadir memeriahkan program ketika itu.

Pelancong domestik juga menjadikan destinasi di Panggung Seni persembahan yang terletak di sebelah Food Court dan Taman Rekreasi di Dataran Lembah. Sebanyak 38.8\% (194 orang) berkunjung ke panggung seni untuk menyaksikan persembahan terbuka. Memandangkan kunjungan ini hanyalah untuk mengisi masa lapang pelancong, mereka telah memperuntukkan selama 1 jam ke 1 jam setengah untuk sama-sama menyaksikan persembahan tersebut. Antara persembahan yang dipersembahkan adalah tarian zapin, persembahan mengait sarung bantal menggunakan kekabu, persembahan nyanyian solo dan berduet dan persembahan ular. Rata-rata pengunjung berpuas hati kerana turut serta dan dapat menyaksikan secara langsung.

Bagi pelancong wanita, tidak sah sekiranya mereka tidak berkunjung ke kedai fesyen dan tekstil tradisional yang terletak di sepanjang deretan kedai-kedai di sekitar Bandar Diraja Kuala Kangsar. Terdapat lebih daripada 30 buah kedai lama yang mempersembahkan pakaian-pakaian lama seperti 
batik (baju dan kain), baju kebaya, baju berasaskan tenunan songket. Begitu juga dengan jualan baju mengikut fesyen semasa. Kunjungan ini nyata memberikan kepuasan kepada pelancong domestik yang gemar membeli belah.

Balai seni visual dan fotografi merupakan destinasi kunjungan lain kepada 35.6\% (178 orang) pelancong domestik. Kebanyakannya adalah daripada segmen belia. Seni visual yang ada di balai seni adalah berbentuk seni tradisional dan jalanan. Gabungan konsep ini memberikan nafas baharu dalam kunjungan pelancong domestik. Seni visual seperti gambaran terdahulu dan sekarang yang diolah kembali menjadi tarikan utama untuk pengunjung turut sama merasai suasana kegemilangan yang dahulunya pernah dirasai oleh masyarakat lama. Namun demikian, kunjungan ini bukanlah secara menyeluruh hasil daripada temu bual dengan responden yang berkunjung.

Kunjungan ke kedai pertukangan tradisional juga dijadikan asas kepada destinasi lain yang menjadi pilihan kunjungan pelancong domestik. Sebanyak 34.6\% (173 orang) menjadikan kedai pertukangan lokasi melawat di Bandar Diraja Kuala Kangsar. Mereka didedahkan dengan teknik-teknik pertukangan secara tradisional dengan menggunakan tangan. Ilmu-ilmu pertukangan kayu ini boleh dijadikan sudu, parang, meja kecil, sarung parang dan gasing. Kebanyakan pelancong yang berkunjung diberi peluang untuk membuat gasing dan dibawa pulang sebagai hadiah cenderamata.

Di samping itu, kunjungan yang paling sedikit dikunjungi oleh pelancong domestik adalah pusat pembuatan dan penjualan kraf tangan iaitu sebanyak 19.4\% (97 orang). Meskipun hampir 30 usahawan tembikar dan seramik Kuala Kangsar yang terlibat aktif dalam pembuatan kraf tangan di Bandar Diraja Kuala Kangsar, namun didapati ia tidak menarik minat pengunjung untuk hadir. Antara yang menjadi tumpuan adalah di Perusahaan tembikar tradisional di Enggor, Kuala Kangsar yang menjadi salah satu projek Kraf Kampungku yang memberi peluang kepada pengunjung untuk merasai sendiri pengalaman membuat labu sayong.

Jadual 4: Destinasi sekunder Kuala Kangsar

\begin{tabular}{lcccc}
\hline \multicolumn{1}{c}{ Destinasi Sekunder } & \multicolumn{2}{c}{ Ya } & \multicolumn{2}{c}{ Tidak } \\
\cline { 2 - 5 } & Bil & $\mathbf{\%}$ & Bil & \% \\
\hline Pusat Pembuatan dan Penjualan Kraf tangan & 97 & 19.4 & 403 & 80.6 \\
Muzium, Galeri \& Arkib & 335 & 67.0 & 165 & 33.0 \\
Panggung Seni & 194 & 38.8 & 306 & 61.2 \\
Balai Seni Visual dan Fotografi & 178 & 35.6 & 322 & 64.4 \\
Kedai Pertukangan Tradisional & 173 & 34.6 & 327 & 65.4 \\
Kedai Fesyen dan Tekstil Tradisional & 190 & 38.0 & 310 & 62.0 \\
Perpustakaan Bahan Kesusasteraan (Perpustakaan Desa) & 201 & 40.2 & 299 & 59.8 \\
\hline
\end{tabular}

\section{Aktiviti Sekunder}

Sebagaimana aktiviti utama menjadi rencah dalam memandu pelancong domestik untuk mengunjungi Bandar Diraja Kuala Kangsar, terdapat juga aktiviti-aktiviti sampingan yang menjadi pendorong terhadap kunjungan. Bandar Diraja Kuala Kangsar tidak ketinggalan dalam menyediakan perkhidmatan pusat hiburan. Antara pusat hiburan yang disediakan adalah pusat karaoke, pusat cenderamata, pusat membeli belah dan pusat kraf tangan.

Berdasarkan dapatan kajian, pusat membeli belah mengambil sebahagian besar 'masa kunjungan', sama ada hari pertama, hari berikutnya mahupun hari terakhir berada di Bandar Diraja. Menurutnya, pilihan mengunjungi pusat membeli-belah bergantung kepada masa. Mereka memilih kepelbagaian jenis pilihan cenderamata, lokasi yang mudah capai serta ruang parkir yang banyak untuk memudahkan mereka parking kereta di tempat yang berdekatan dan selamat. Majoriti pelancong memilih pusat membeli-belah sebagai aktiviti berkunjung.

Seterusnya, pelancong domestik juga tidak melepaskan peluang untuk berkunjung ke pusat cenderamata iaitu sebanyak $56.8 \%$ (284 orang). Walaupun ada cenderamata yang mudah didapati di 
destinasi pelancongan lain, namun terdapat perbezaan produk cenderamata yang diperkenalkan. Antaranya adalah tudung saji rotan, beg raga rotan, kerusi rotan, keris dan sarung keris, rehal (meja AlQuran) dan lain-lain produk yang jarang sekali didapati di tempat pelancongan lain.

Pusat kraf tangan juga menjadi salah satu aktiviti yang dikunjungi pelancong domestik. Sebanyak $54.2 \%$ (271 orang) berkunjung ke pusat kraf tangan dan mereka berasa puas hati kerana diberi kesempatan untuk melihat dan merasai sendiri pengalaman membuat labu sayong. Mereka juga belajar membuat sulaman tekat menggunakan emas dan juga membuat sendiri keris. Aktiviti berkunjung ke pusat kraf tangan tidak disia-siakan oleh mereka kerana banyak ilmu pengetahuan dan pengalaman yang diperoleh di samping keseronokan membuatnya.

Kebanyakan pelancong mengetahui bahawa di Kuala Kangsar, tidak terdapat banyak pusat hiburan. Malah tidak ada panggung wayang dan pusat permainan untuk kanak-kanak. Walaupun terdapat pusat karaoke, ia tidak menarik minat pelancong untuk menghabiskan masa bersama keluarga dan temanteman. Pusat karaoke yang terdapat di sekitar Kuala Kangsar tidak mempunyai tarikan dan agak suram dan menakutkan. Kemungkinan suasana malam yang tidak meriah di sekitar pusat karaoke berbanding dengan kawasan lain. Oleh itu, tidak ramai pelancong yang menjadikan karaoke sebagai aktiviti sampingan.

Jadual 5: Kunjungan ke pusat hiburan

\begin{tabular}{lcccc}
\hline \multicolumn{1}{c}{ Kunjungan Pusat Hiburan } & \multicolumn{2}{c}{ Ya } & \multicolumn{2}{c}{ Tidak } \\
\cline { 2 - 5 } & Bil & \% & Bil & \% \\
\hline Pusat karaoke & 88 & 17.6 & 412 & 82.4 \\
Pusat cenderamata & 284 & 56.8 & 216 & 43.2 \\
Pusat membeli-belah & 344 & 68.8 & 156 & 31.2 \\
Pusat kraf tangan & 271 & 54.2 & 229 & 45.8 \\
\hline
\end{tabular}

\section{Tujuan Memilih Ke Bandar Diraja}

Terdapat lima tujuan utama pelancong memilih untuk berkunjung ke Bandar Diraja. Tujuan memilih berkunjung ke Bandar Diraja Kuala Kangsar kerana kepelbagaian matlamat. Hasil analisis mendapati lebih 50\% pelancong memilih Bandar Diraja Kuala Kangsar sebagai destinasi kunjungan kerana ingin memenuhi rasa ingin tahu tentang Bandar Diraja Kuala Kangsar yang dikenali sebagai Bandar warisan dan Diraja. Hal ini kerana Bandar Diraja mempunyai keunikan Diraja yang tidak terdapat di bandarbandar yang lain. Dalam konteks pendidikan pula, sebanyak $45.5 \%$ pelancong memilih Bandar Diraja kerana ingin mempelajari adat istiadat, aktiviti kesenian dan bahasa pertuturan harian masyarakat di Kuala Kangsar. Hasil min tertinggi adalah sebanyak 3.99 iaitu merasai budaya dan gaya hidup di Bandar Diraja. Oleh itu, kajian mendapati pelancong memilih Bandar Diraja kerana nilai Diraja yang menjadi tarikan utama pelancong domestik. Oleh itu, kajian mendapati pelancong memilih Bandar Diraja kerana nilai Diraja yang menjadi tarikan utama pelancong domestik. Hal ini menjelaskan bahawa pelancong mempunyai pilihan yang pelbagai tetapi ingin mengenali identiti Bandar Diraja menerusi aspek komersial, reka bentuk dan budaya Bandar Diraja.

Jadual 6: Tujuan Memilih Bandar Diraja

\begin{tabular}{lcccccccccc}
\hline Item & \multicolumn{2}{c}{$\begin{array}{c}\text { Sangat } \\
\text { Rendah }\end{array}$} & Rendah & Sederhana & \multicolumn{2}{c}{ Tinggi } & \multicolumn{2}{c}{$\begin{array}{c}\text { Sangat } \\
\text { Tinggi }\end{array}$} \\
\cline { 2 - 11 } & Bil & \% & Bil & \% & Bil & \% & Bil & \% & Bil & $\%$ \\
\hline $\begin{array}{l}\text { Memenuhi rasa ingin } \\
\text { tahu }\end{array}$ & 8 & 1.6 & 17 & 3.4 & 137 & 27.4 & 257 & 51.4 & 81 & 16.2 \\
$\begin{array}{l}\text { Mempelajari perkara } \\
\text { baru dalam diri }\end{array}$ & 9 & 1.8 & 28 & 5.6 & 119 & 23.8 & 227 & 45.4 & 117 & 23.4 \\
$\begin{array}{l}\text { Berjumpa dengan } \\
\text { orang baru }\end{array}$ & 14 & 2.8 & 48 & 9.6 & 139 & 27.8 & 181 & 36.2 & 118 & 23.6 \\
Meningkatkan & 5 & 1.0 & 39 & 7.8 & 125 & 25.0 & 191 & 38.2 & 140 & 28.0 \\
\hline
\end{tabular}


DOI: https://doi.org/10.47405/mjssh.v5i1.348

\begin{tabular}{lllllllllll}
\hline $\begin{array}{l}\text { kemahiran warisan } \\
\begin{array}{l}\text { Merasai budaya dan } \\
\text { gaya hidup di Bandar } \\
\text { Diraja }\end{array}\end{array}$ & 3 & 0.6 & 30 & 6.0 & 98 & 19.6 & 206 & 41.2 & 163 & 32.6 \\
\hline
\end{tabular}

\section{Faktor Pengaruh Kunjungan}

Dari segi faktor yang dipertimbangkan, sebanyak 50.8\% (254 orang) pelancong memilih tarikan Bandar Diraja sebagai faktor utama. Pelancong juga mempertimbangkan kemudahan-kemudahan awam yang fleksibel sebanyak $48.8 \%$ (244 orang). Terdapat hampir $40 \%$ yang mempertimbangkan tempoh dan jarak perjalanan ke destinasi dan juga waktu perjalanan lawatan. Seterusnya terdapat pelancong yang mempertimbangkan waktu perjalanan melancong iaitu 45.2\% (226 orang). Di samping itu juga, terdapat hampir $45 \%$ pelancong yang mempertimbangkan tahap keselamatan yang tinggi dan pengangkutan yang digunakan sebagai faktor yang dipertimbangkan sebelum melancong. Hasil faktor yang dipertimbangkan ini menunjukkan bahawa tarikan-tarikan yang berada di Bandar Diraja mengembalikan semula kekayaan masa lalu yang bernilai prestij tinggi serta pengekalan ini memelihara dan memulihara kelangsungan Bandar Diraja pada masa hadapan.

Jadual 7: Faktor kunjungan ke Bandar Diraja

\begin{tabular}{|c|c|c|c|c|c|c|c|c|c|c|}
\hline \multirow[t]{2}{*}{ Item } & \multicolumn{2}{|c|}{$\begin{array}{l}\text { Sangat } \\
\text { Rendah }\end{array}$} & \multicolumn{2}{|c|}{ Rendah } & \multicolumn{2}{|c|}{ Sederhana } & \multicolumn{2}{|c|}{ Tinggi } & \multicolumn{2}{|c|}{$\begin{array}{l}\text { Sangat } \\
\text { Tinggi }\end{array}$} \\
\hline & Bil & $\%$ & Bil & $\%$ & Bil & $\%$ & Bil & $\%$ & Bil & $\%$ \\
\hline $\begin{array}{l}\text { Tarikan Bandar } \\
\text { Diraja }\end{array}$ & 6 & 1.2 & 16 & 3.2 & 85 & 17.0 & 254 & 50.8 & 139 & 27.8 \\
\hline $\begin{array}{l}\text { Kos } \\
\text { perbelanjaan }\end{array}$ & 5 & 1.0 & 20 & 4.0 & 115 & 23.0 & 205 & 41.0 & 155 & 31.0 \\
\hline $\begin{array}{l}\text { Kebenaran ibu } \\
\text { bapa dan } \\
\text { keluarga }\end{array}$ & 4 & 0.8 & 29 & 5.8 & 89 & 17.8 & 211 & 42.2 & 167 & 33.4 \\
\hline $\begin{array}{l}\text { Waktu } \\
\text { perjalanan } \\
\text { lawatan }\end{array}$ & 3 & 0.6 & 26 & 5.2 & 99 & 19.8 & 226 & 45.2 & 146 & 29.2 \\
\hline $\begin{array}{l}\text { Pengangkutan } \\
\text { persendirian dan } \\
\text { awam }\end{array}$ & 6 & 1.2 & 23 & 4.6 & 100 & 20.0 & 219 & 43.8 & 152 & 30.4 \\
\hline $\begin{array}{l}\text { Tempoh dan } \\
\text { jarak perjalanan } \\
\text { ke destinasi }\end{array}$ & 5 & 1.0 & 19 & 3.8 & 95 & 19.0 & 235 & 47.0 & 146 & 29.2 \\
\hline $\begin{array}{l}\text { Kemudahan- } \\
\text { kemudahan } \\
\text { awam yang } \\
\text { fleksibel }\end{array}$ & 3 & 0.6 & 20 & 4.0 & 93 & 18.6 & 244 & 48.8 & 140 & 28.0 \\
\hline $\begin{array}{l}\text { Tahap } \\
\text { keselamatan } \\
\text { yang tinggi }\end{array}$ & 2 & 0.4 & 18 & 3.6 & 93 & 18.6 & 221 & 44.2 & 166 & 33.2 \\
\hline
\end{tabular}


DOI: https://doi.org/10.47405/mjssh.v5i1.348

\section{Keperluan Perkhidmatan di Bandar Diraja}

\section{Sumber Maklumat}

Sepanjang berada di Bandar Diraja Kuala Kangsar, pengunjung menggunakan laman sesawang seperti Facebook, Instagram dan media sosial yang lain untuk memperoleh informasi tentang Bandar Diraja dan destinasi lain untuk kunjungan di waktu lapang sepanjang berada di sana. Sebanyak $42.8 \%$ pengunjung menggunakan iklan dan risalah yang didapati di hotel penginapan dan sepanjang perjalanan mereka untuk sampai ke destinasi yang ditujui. Risalah tersebut membantu responden untuk memilih pakej-pakej yang ditawarkan oleh destinasi pelancongan tersebut. Oleh itu, laman sesawang dan risalah pakej pelancongan Bandar Diraja merupakan sumber maklumat utama pelancong sepanjang berada di Bandar Diraja. Kesimpulan, laman sesawang mahupun media elektronik mempengaruhi pelancong membuat keputusan dalam menerima maklumat berkaitan pelancongan Bandar Diraja. Ini kerana pelancong sangat aktif dalam menyebarkan maklumat dengan rangkaian sosial yang boleh mempengaruhi.

Jadual 8: Sumber Maklumat

\begin{tabular}{|c|c|c|c|c|c|c|c|c|c|c|}
\hline \multirow[t]{2}{*}{ Item } & \multicolumn{2}{|c|}{$\begin{array}{c}\text { Sangat } \\
\text { Rendah }\end{array}$} & \multicolumn{2}{|c|}{ Rendah } & \multicolumn{2}{|c|}{ Sederhana } & \multicolumn{2}{|c|}{ Tinggi } & \multicolumn{2}{|c|}{$\begin{array}{l}\text { Sangat } \\
\text { Tinggi }\end{array}$} \\
\hline & Bil & $\%$ & Bil & $\%$ & Bil & $\%$ & Bil & $\%$ & Bil & $\%$ \\
\hline Iklan dan risalah & 14 & 2.8 & 46 & 9.2 & 133 & 26.6 & 212 & 42.4 & 95 & 19.0 \\
\hline $\begin{array}{l}\text { Laman sesawang } \\
\text { seperti FB, IG } \\
\text { danTwitter }\end{array}$ & 10 & 2.0 & 40 & 8.0 & 72 & 14.4 & 214 & 42.8 & 164 & 32.8 \\
\hline $\begin{array}{l}\text { Ekspo dan } \\
\text { pameran } \\
\text { pelancongan }\end{array}$ & 23 & 4.6 & 42 & 8.4 & 137 & 27.4 & 172 & 34.4 & 126 & 25.2 \\
\hline TV / Radio & 18 & 3.6 & 50 & 10.0 & 118 & 23.6 & 207 & 41.4 & 107 & 21.4 \\
\hline Lisan & 21 & 4.2 & 75 & 15.0 & 125 & 25.0 & 176 & 35.2 & 103 & 20.6 \\
\hline
\end{tabular}

\section{Penginapan}

Di kalangan mereka, sebahagian besar masa kunjungan berlaku di tempat penginapan. Beberapa aspek di sini secara langsung menunjukkan mereka berada dalam ruang yang dikunjungi ramai atau sebaliknya. Hotel merupakan penginapan utama mereka. Ia menjadi pilihan pertama apabila melancong walaupun hotel tersebut bertaraf tiga bintang iaitu sebanyak 50.6\% (253 orang). Memandangkan di Kuala Kangsar, kebanyakan hotel penginapan bertaraf tiga bintang, ia tidak menjadi masalah kepada mereka kerana terdapat banyak ruang terbuka seperti ruang restoran, ruang receptionist dan kolam renang. Memandangkan terdapat hotel yang mempunyai ruang terhad, banyak masa digunakan di luar hotel. Hotel dijadikan sebagai tempat tidur, menyalin pakaian dan beristirahat sebentar sahaja.

Jadual 9: Penginapan

\begin{tabular}{lcccc}
\hline \multirow{1}{*}{ Penginapan } & \multicolumn{2}{c}{ Ya } & \multicolumn{2}{c}{ Tidak } \\
\cline { 2 - 5 } & Bil & $\mathbf{\%}$ & Bil & \% \\
\hline Hotel & 253 & 50.6 & 247 & 49.4 \\
Resort & 130 & 26.0 & 370 & 74.0 \\
Homestay & 174 & 34.8 & 326 & 65.2 \\
Rumah rakan atau saudara mara & 140 & 28.0 & 360 & 72.0 \\
Rumah tumpangan & 97 & 19.4 & 403 & 80.6 \\
\hline
\end{tabular}

\section{Mod Pengangkutan}

Pengangkutan merupakan salah satu keperluan wajib dalam pelancongan kerana fungsi utamanya adalah untuk mempercepatkan pergerakan dari satu destinasi ke destinasi yang lain dalam masa yang 
singkat. Dari segi pengangkutan, pelancong domestik menggunakan kenderaan persendirian iaitu $79.6 \%$ (398 orang) kerana membawa bilangan ahli keluarga yang ramai. Terdapat juga sebanyak $25.6 \%$ (128 orang) pelancong yang menggunakan pengangkutan awam seperti teksi dan bas. Seterusnya terdapat pelancong yang menggunakan perkhidmatan kenderaan sewa iaitu 23.6\% (118 orang). Hal ini kerana terdapat banyak kenderaan sewa yang disediakan di sekitar Bandar Diraja Kuala Kangsar dan murah di samping kondisi kenderaan sewa yang baik. Antara kenderaan sewa yang digunakan adalah kereta Myvi, AXIA dan SAGA.

Jadual 10: Pengangkutan

\begin{tabular}{lcccc}
\hline \multirow{2}{*}{ Kunjungan Pusat Hiburan } & \multicolumn{2}{c}{ Ya } & \multicolumn{2}{c}{ Tidak } \\
\cline { 2 - 5 } & Bil & \% & Bil & \% \\
\hline Kenderaan Persendirian & 398 & 79.9 & 102 & 20.1 \\
Pengangkutan Awam & 128 & 25.6 & 372 & 74.4 \\
Kenderaan Sewa & 118 & 23.6 & 382 & 76.4 \\
\hline
\end{tabular}

\section{Perbelanjaan Ketika Berkunjung}

Perbelanjaan memainkan peranan penting dalam memastikan kunjungan pelancong domestik secara menyeluruh. Kajian memberi tumpuan kepada perbelanjaan di tapak pelancongan, penginapan, sepanjang kunjungan, makan dan minum serta bayaran masuk. Hasil menunjukkan hampir $82 \%$ pelancong membayar <RM100 untuk lawatan ke 'site'. Seterusnya, untuk perbelanjaan bagi penginapan pula, terdapat dua jenis penginapan yang digunakan oleh pelancong iaitu $<$ RM100 dan $>$ RM2001. Ini kerana terdapat pelancong berkeluarga yang menginap di hotel manakala terdapat pelancong yang menginap di hotel bajet dan homestay murah. Di samping itu, sepanjang perjalanan di Bandar Diraja seperti bayaran masuk ke tandas awam, mengisi minyak kereta serta lain-lain menunjukkan pelancong membayar $<$ RM100 iaitu 57.6\% (317 orang). Dari segi perbelanjaan makanminum, hampir $63 \%$ pelancong berbelanja $<$ RM100 serta $>$ RM2001. Ini kerana harga makanan yang berpatutan serta makanan asli. Bagi perbelanjaan yang >RM2001 adalah kerana ahli keluarga yang ramai perlu memperuntukkan perbelanjaan yang lebih tinggi. Bagi bayaran masuk ke tempat warisan mendapati hampir $78 \%$ berbelanja sebanyak $<$ RM100.

Jadual 11: Perbelanjaan Keseluruhan

\begin{tabular}{|c|c|c|c|c|c|c|c|c|c|c|}
\hline \multirow[t]{2}{*}{ Komponen } & \multicolumn{2}{|c|}{$\begin{array}{c}\text { Lawatan ke } \\
\text { 'site' }\end{array}$} & \multicolumn{2}{|c|}{$\begin{array}{c}\text { Penginapan } \\
\text { di Bandar } \\
\text { Diraja }\end{array}$} & \multicolumn{2}{|c|}{$\begin{array}{c}\text { Sepanjang } \\
\text { perjalanan } \\
\text { di Bandar } \\
\text { Diraja }\end{array}$} & \multicolumn{2}{|c|}{$\begin{array}{l}\text { Makan - } \\
\text { Minum }\end{array}$} & \multicolumn{2}{|c|}{$\begin{array}{c}\text { Bayaran } \\
\text { masuk di } \\
\text { tempat- } \\
\text { tempat } \\
\text { warisan }\end{array}$} \\
\hline & Bil & $\%$ & Bil & $\%$ & Bil & $\%$ & Bil & $\%$ & Bil & $\%$ \\
\hline$<\mathrm{RM} 100$ & 408 & 81.6 & 264 & 52.8 & 288 & 57.6 & 317 & 63.4 & 389 & 77.8 \\
\hline $\begin{array}{l}\text { RM101- } \\
\text { RM500 }\end{array}$ & 87 & 17.4 & 221 & 44.2 & 189 & 37.8 & 170 & 34.0 & 98 & 19.6 \\
\hline $\begin{array}{l}\text { RM501- } \\
\text { RM1000 }\end{array}$ & 2 & 0.4 & 12 & 2.4 & 19 & 3.8 & 9 & 1.8 & 8 & 1.6 \\
\hline $\begin{array}{l}\text { RM1001- } \\
\text { RM1500 }\end{array}$ & 1 & 0.2 & 2 & 0.4 & 2 & 0.4 & 2 & 0.4 & 3 & 0.6 \\
\hline $\begin{array}{l}\text { RM1501- } \\
\text { RM2000 }\end{array}$ & 1 & 0.2 & 1 & 0.2 & 1 & 0.2 & 2 & 0.4 & - & - \\
\hline$>$ RM 2001 & 1 & 0.2 & 264 & 52.8 & 1 & 0.2 & 317 & 63.4 & 2 & 0.4 \\
\hline
\end{tabular}

\section{Waktu Kunjungan}

Sebanyak $62.0 \%$ pelancong memilih untuk berada di Bandar Diraja selama $1-2$ hari manakala sebanyak $30.8 \%$ pelancong memilih tempoh masa selama 3 - 4 hari. Hasil analisis mendapati tempoh masa terhad kepada pelancong domestik yang bekerja dan mereka memilih untuk berkunjung pada hari 
Sabtu dan Ahad sahaja. Waktu cuti yang terhad serta tempoh perjalanan dari satu destinasi lain yang dekat menjadikan tempoh masa kunjungan adalah singkat. Hal ini juga disebabkan lawatan ke muzium dan bangunan bersejarah hanya mengambil masa yang singkat antara 1 jam hingga 2 jam sahaja. Hampir $40 \%$ pelancong berkunjung ke Bandar Diraja pada waktu cuti persekolahan manakala sebanyak $35.6 \%$ pelancong hadir pada hujung minggu. Ini kerana pada waktu cuti persekolahan, terdapat aktiviti-aktiviti sampingan yang disediakan di sekitar kawasan tumpuan Bandar Diraja. Pelancong juga lebih gemar berkunjung bersama keluarga dan bergerak solo. Hasil mendapati pelancong yang berkeluarga memilih seisi keluarga untuk turut serta manakala pelancong yang melancong bersama rakan-rakan memilih rakan sekolah berbanding dengan rakan kerja mahupun rakan universiti.

Jadual 12: Waktu kunjungan

\begin{tabular}{llcccc}
\hline \multirow{2}{*}{ Komponen } & \multirow{2}{*}{ Item } & \multicolumn{3}{c}{ Ya } & \multicolumn{2}{c}{ Tidak } \\
\cline { 3 - 6 } & & Bil & \% & Bil & \% \\
\hline Tempoh masa kunjungan & Seminggu & 103 & 20.6 & 397 & 79.4 \\
& 1 - 2 Hari & 310 & 62.0 & 190 & 38.0 \\
& 3 - 4 Hari & 154 & 30.8 & 346 & 69.2 \\
& 5 - 6 Hari & 63 & 12.6 & 437 & 87.4 \\
& > Seminggu & 67 & 13.4 & 433 & 86.6 \\
& & & & \\
Kesesuaian Waktu & Hujung minggu & 178 & 35.6 & 322 & 64.4 \\
& Setiap hujung bulan & 65 & 13.0 & 435 & 87.0 \\
& Cuti Semester & 121 & 24.2 & 379 & 75.8 \\
& Cuti Persekolahan & 196 & 39.2 & 304 & 60.8 \\
& Bila-bila masa & 161 & 32.2 & 339 & 67.8 \\
\hline
\end{tabular}

\section{Perbincangan}

Hasil perbincangan mendapati Bandar Diraja Kuala Kangsar semakin berkembang selepas menjadikan bandar ini sebagai produk pelancongan. Kunjungan pelancong meningkatkan menerusi pertambahan kehadiran pelancong di Bandar Diraja Kuala Kangsar. Perkembangan pelancongan ini bukan sahaja daripada golongan berpendidikan tetapi golongan berpendidikan sederhana juga mengambil peluang untuk melancong ke Bandar Diraja atas tujuan-tujuan tertentu. Faktor utama yang mendukung pilihan melancong ke Bandar Diraja adalah untuk memenuhi rasa ingin tahu tentang identiti zaman kegemilangan Bandar Diraja sebagai pusat utama pentadbiran pada masa dahulu. Selain daripada melihat sendiri imej-imej dan perlambangan Bandar Diraja yang tidak terdapat di mana-mana Bandar Diraja yang lain. Namun demikian, terdapat juga sub-sub komponen yang menjadi pilihan pelancong domestik untuk datang ke Bandar Diraja. Antara pilihan utamanya adalah tarikan-tarikan berbentuk semula jadi yang terdapat di Bandar Diraja. Pola kunjungan pelancong domestik juga menunjukkan waktu kunjungan serta tempoh kunjungan mereka adalah pada waktu cuti persekolahan, cuti-cuti umum mahupun cuti khas yang diberikan. Selain itu tempoh kunjungan juga adalah di antara 1-4 hari. Oleh itu, jelas menunjukkan bahawa trend kunjungan ke Bandar Diraja adalah waktu-waktu padat dengan cuti dan kemeriahan Bandar Diraja ditonjolkan untuk menarik minat pelancong domestik untuk datang kembali ke Bandar Diraja. Seterusnya, laman sesawang digunakan pelancong untuk mendapatkan maklumat-maklumat tambahan berkenaan dengan destinasi kunjungan. Hasil mendapati, pelancong domestik telah membuat perancangan awal sebelum memulakan kunjungan ke Bandar Diraja. Seterusnya, perjalanan semasa pelancong domestik adalah mengikut segmen yang telah dibuat pada awal perancangan. Ia bertujuan untuk memandu mereka untuk menjayakan perjalanan pelancongan Bandar Diraja serta mereka dapat memenuhi tuntutan kehendak mereka sepanjang melancong. 


\section{Kesimpulan}

Pola pelancongan dalam kalangan pelancong domestik menunjukkan kehadiran yang tinggi walaupun pelancong domestik mempunyai perbezaan dari segi status ekonomi dan sosial, namun demikian mempunyai cirian yang hampir sama seperti menjalankan aktiviti pelancongan yang sama berserta dengan matlamat dan tujuan kehadiran ke Bandar Diraja adalah sama. Kajian tentang pelancongan di Bandar Diraja telah berkesinambungan dari dahulu lagi.

\section{Rujukan}

Blank, U.E.L. (1994). Research on urban tourism destinations. Dlm Ritchie, J.R. \& Goeldner, C.R. pynt.. Travel, tourism and hospitality research. Edisi ke-2. New York: John Wiley and sons.

Anuar ANA, Habibah A, Hamzah J, Hussain MY. (2012). The essential element underlying formation of tourist friendly destination concept. Journal of Management and Sustainability, 2(1): 106-114.

Khoshpakyants, A.V., \& Vidishcheva, E.V. (2010). Challenges of youth tourism. European researcher. (1): 101-103.

Mair, J., \& Withford, M. (2013). An exploration of events research: event topics, themes and emerging trends. International Journal of Event and Festival Management, 4(1): 6-30.

Kim, J., Boo, S., \& Kim, Y. (2013). Pattern and trends in event tourism study topics over 30 years. International Journal of Event and Festival Management, 4(1): 66-83).

Jabatan Perangkaan Malaysia. (2017). Siaran Akhbar Penyiasatan Pelancongan Domestik 2016.

Anuar ANA, Habibah A, Hamzah J, Hussain MY, Buang A, Samsir SW. (2014). Pembentukan destinasi mesra pelancong berasakan perspektif pelancong domestik. Malaysian Journal of Society and Space, 10(8) 1-12.

Habibah Ahmad, Hamzah Jusoh, Noor Alyani Noor Azizi \& Anisah Samingan. (2007). Tahun Melawat Malaysia 2007: Respons belia terhadap pelancongan acara.

Ghaffar, A. (2000). Pemuliharaan dan pengurusan bangunan warisan di Malaysia. Kertas Kerja yang telah dibentangkan di Seminar Warisan Budaya dan Pelancongan: Ke arah Pengurusan Lestari di Hotel Helang.1-2 November 2000.

Wall, G. (1994). Change, impact and opportunities: turning victims into victors, paper presented at the expert meeting on "Sustainability in Tourism and Leisure", Tilburg.

Tedd., L.A. (2010). People's collection wales. Online access to the heritage of Wales from museums, archive and libraries, 45(3): 333-345.

Borg, J.V.B., Paola Costa, P., \& Gotti. G. (1996). Tourism in European heritage cities. Annal of Tourism Research, 23(2): 306-321.

Fenton, C. (2007). Finding the way. Improving Access To The Collections Of The Royal Scottish Geographical Society, 41(4): 353-364.

Tao, W., \& Luca, Z. (2011). Management and presentation Chinese sites for UNESCO World Heritage lis (UWHL). Facilities, 29(7/8): 313-325.

Balmer, J.M.T. (2009). Scrutinizing the British monarchy: the corporate brand was shaken, stirred and survived. Management Decision, 47(4): 639-675.

Sims, F. (2002). A new appraisal approach for English heritage. Record Management Journal, 10(2): 87-107.

Inglehart, R., \& Baker, W.E. (2000). Modernization, cultural change, and the persistence of traditional value. American Sociological Review, 65(1): 19-51.

Ula, H., Sonja, L., \& Birgitta, S. (2011). Operationalising brand heritage and cultural heritage. Journal of Product \& Brand Management, 20(6): 447-456.

Banerjee, S. (2008). Strategic brand-cultural fit: a conceptual framework for brand management. Journal of Brand Management, 15(5): 312-321.

Natalie M. Underberg-Goode. (2016). Cultural heritage tourism on Peru's north coast. Worldwide Hospitality and Tourism Themes, 6(3):200-214.

Prentice, R. \& Cunnel, D. (1998). Response to interpretative media a basis of multi variate market segmentation for museums and heritage centres: the case example of the people's story, Edinburgh. Museum Management and Curatorship, 16(3): 233-256. 
Deborah Cunnel \& Richard Prentice. (2001). Tourist's recollections of quality in museums: a services cape without people? Museum Management and Curatorship, 18(4):369-390.

Dobson, S \& Selman, P. (2012). Applying historic landscape characterization in spatial planning: from remnants to remanence. Planning Practice \& Research 27(4):459-474

Esther H.K Yung, Lawrence W.C Lai \& Philip L.H. Yu. (2016). Public decision making for heritage conservation: A Hong Kong empirical study. Habitat International 53(16):312-319.

Garcia, E.P. (2007). The destruction of a cultural heritage: with reference to the problems of Iraq. New Library World, 108 (7): 354-369. 